\title{
Cultural Competence in the Prevention and Treatment of Cancer: The Case of Blueberries in North America
}

\author{
Niobra Samuel-Peterson \\ Department of Sociology, University of North Carolina at Chapel Hill, Chapel Hill, USA \\ Email: nmpeters@email.unc.edu
}

Received February $14^{\text {th }}, 2013$; revised March $14^{\text {th }}, 2013$; accepted March $24^{\text {th }}, 2013$

\begin{abstract}
Copyright (C) 2013 Niobra Samuel-Peterson. This is an open access article distributed under the Creative Commons Attribution License, which permits unrestricted use, distribution, and reproduction in any medium, provided the original work is properly cited
\end{abstract}

\begin{abstract}
Berry and berry-type fruits have gained the title of "super fruits" in recent years due to their anti-disease promoting phytonutrients. While researchers have been hard at work isolating the mechanisms by which these bioactive chemicals influence the human body, scientists have largely ignored the influence of culture on the co-evolutionary relationship between berry fruits and humans. This paper explores the phytochemical makeup and cultural groundings of blueberries (Vaccinium corymbosum). Cultural and spiritual connections of northeastern Native American groups such as the Ojibwe tribe with blueberries have influenced the survival of both species. Considering the poor consumption of fruits across the United States, this paper presents the thesis that effectively changing the dietary habits of a population requires a multifaceted approach where scientific knowledge of the benefits of fruits in addition to the history and sociocultural meaning of various fruits are taken into account. Moreover, this paper discusses the importance of sociocultural backgrounds (specifically of fruits) as a platform for strengthening cultural competence in order to more effectively communicate knowledge concerning the use of fruits in the prevention and treatment of various cancers.
\end{abstract}

Keywords: Blueberries; Berry Fruits; Cultural Competence; Cancer

\section{Introduction}

In the movement towards gene specific dietary campaigns and medical care, it is increasingly important to understand the relationships that specific populations have with plants. Many berry and berry-type fruits have been found to have a profound impact on the culture and biochemistry of human populations. These so called "super-fruits" have been singled out for their anti-cancer, anti-inflammatory, anti-aging, and anti-neurodegenerative properties (Brown et al., 2012; Rendeiro et al., 2012; Varoni et al., 2012; Mates et al., 2011; Meydani \& Hasan, 2010; Seeram, 2008a; Seeram, 2008b; Szajdek \& Borowska, 2008). Berry fruits popularly found in North American markets include blueberries (Vaccinium corymbosum), cranberries (Vaccinium macrocarpon), blackberries (Rubus spp.), black raspberries (Rubus occidentalis), red raspberries (Rubus idaeus) and strawberries (Fragaria ananassa). There is also a growing trend in the sale of exotic "berry-type" fruits, including the pomegranate (Punica granatum), goji berries (Lycium barbarum; also known as the wolfberry), fruits of Garcinia mangostana, the Brazilian açaí berry (Euterpe oleraceae), and the Chilean maqui berry (Aristotelia chilensis).

In recent years, the scientific community has taken steps to increase and synthesize research on the health benefits of berry fruits (Seeram, 2011; Seeram, 2008a). In 2005, the first International Berry Health Benefits Symposium was held in Corvallis, Oregon. The purpose of this biennial conference series was "to explore the latest scientific research related to berry consumption and human health" (Seeram, 2008a). Current studies have explained the anti-inflammatory, anti-neurodegenerative, and antioxidant properties in berries as linked to their abundance of phytochemicals (Brown et al., 2012; Rendeiro et al., 2012; Varoni et al., 2012; Mates et al., 2011; Seeram, 2011; Meydani \& Hasan, 2010; Wood, 2010; Seeram, 2008a; Seeram, 2008b; Szajdek \& Borowska, 2008; Wu et al., 2004). Phytochemicals (or phytonutrients) are non-nutritive elements of berries (and other fruits and vegetables) that are bioactive and have positive benefits on human health (Stoner \& Seeram, 2011). Though more scientific research is needed to further define the human health benefits of specific berries, there is consensus that berries have extraordinary anti-disease potential (Brown et al., 2012; de Kok, 2012; Renderio et al., 2012; Varoni et al., 2012; Mates et al., 2011; Stoner \& Seeram, 2011; Wood, 2010; Seeram, 2008a; Stan et al., 2008; Parry et al., 2006; Wu et al., 2004).

While a vast array of berry and berry-type fruits are consumed in North America, this paper focuses on blueberries for its rich cultural history and anti-cancer agents. The blueberry has strong social, economic, and spiritual co-evolutionary lineages that binds the fruit to specific human populations and ensures the survival of both berries and humans. For example, the blueberry is also known as the "star berry" to some Native American tribes and is recognized as a gift from the Great Spirit (Sliver \& Allen, 2012; Norrgard, 2009). The traditional practice of gathering berries (called "berrying") echoed the gathering practices of early humans and brought income to Native American tribes throughout the European conquest of North American territory (Norrgard, 2009). To modern citizens of the 
United States, the blueberry is a fruit that is tied to a sense of nationalism due origins in North America. "Indeed, if anything is more American than apple pie, it has to be blueberries," exclaimed reporter Peter Tonge (1980). In this paper, I argue that clinician and researcher knowledge of the blueberry in the context of Native American and modern American society can contribute to strengthening cultural competence within the American healthcare system, therefore expanding the foundation by which providers can communicate with patients and improving patient-provider relationships.

Moreover, a significant body of research explores the anticancer properties of berry and berry-type fruits, drawing conclusions about the anti-cancer potential of singular berry constituents (Seeram, 2008a; Seeram, 2008b; Seeram et al., 2006). Cancer, in the United States is the second leading cause of mortality (Siegel, 2012; CDC, 2011). Some believe cancer will soon overtake heart disease as the leading cause of death for Americans (Siegel et al., 2012). The literature, however, largely ignores the culture surrounding blueberry cultivation and its emergence as a super fruit. This background is important for two primary reasons: first, it helps researchers to understand the types of cultivars that are consumed and why. Second, background is needed to accurately identify strategies by which specific human populations are targeted for national consumption campaigns. This paper focuses on co-evolutionary relationships between humans and blueberries. First, I describe the berry's cultivation, and its cultural history with the Ojibwe natives and the broader American population. I then explore empirical studies and reviews on the biochemistry of blueberries, paying special attention to those bioactive compounds that are useful in the prevention and treatment of cancer. Finally, I discuss the importance of cultural background in the healthcare setting and provide suggestions for healthcare professionals wishing to increase their cultural competence in order to more effectively encourage the consumption of super fruits for cancer treatment and prevention purposes.

\section{Background}

Co-evolution refers to the reciprocal evolutionary change driven by natural selection between two interacting species, for example, fruits and humans (Thompson, 2005). Wild berries were a notable source of nutrients for early hunter gathering societies (Kaplan, 2011). Early humans most likely took cues from animals for introductions to various fruits with anti-disease and nutritional properties. Berries were particularly attractive to humans because of their hues of blue-violet and red during ripe seasons and their natural sweetness.

\section{Blueberries}

The blueberry (Vaccinium) is native to North America. Records of blueberries in American and native culture have dated back well before the $20^{\text {th }}$ century. "When Samuel de Champlain discovered Lake Huron in 1616, he found Indians adding blueberries to sautauthig, a dish he described in his diary as delicious. The Pilgrims were visited by friendly Indians in Plymouth and presented with huge wicker baskets of dried blueberries. And one of the first meals Lewis and Clark ate around the campfire with the Indians of the Northwest Territory was smoke-dried venison with blueberries," reports Marie Bianco of the San Francisco Chronicle (1988).
Today, blueberries grow in three major varieties highbush (corymbosum), rabbiteye (ashei), and lowbush (angustifolium). ${ }^{1}$ Highbush blueberries are most widely cultivated across the US. The highbush blueberry originates in the Northern regions of North America (USDA, 2012). Frederick Coville, US Department of Agriculture botanist, and Elizabeth Coleman White are given credit for the commercial cultivation of the highbush berry. Together they found that blueberries flourish in moist, acidic soil ( $\mathrm{pH} 4.5$ - 4.8) and require cross-pollination for breeding (Kaplan, 2011). Coville and White uncovered these facts between 1911 and 1913, which makes these highbush blueberries amongst the most recently domesticated crops in the region (Kaplan, 2011). Results of Coville and White's crosspollination breeding selected for the larger berries often found in supermarkets today (Sliver \& Allen, 2012; Kaplan, 2011). The highbush blueberry can grow to be a maximum height of 12 feet (USDA, 2012). Rabbiteye blueberries, also known as the southern black blueberry, are most commonly found in the southeastern United States (USDA, 2012). Rabbiteye bushes can grow to be 3 - 6 feet in height (USDA, 2012). Lowbush blueberries are a "wild" variety initially found in eastern and central Canada and the Northeastern US regions of North America (USDA, 2012). Lowbush berries, characterized by a smaller berry, are more difficult to cultivate. These berries grow to a maximum height of only 2 feet (USDA, 2012). Though particular about the acidity of the soil, blueberries are a resilient crop that thrives on recently burned land (Sliver \& Allen, 2012; Kaplan, 2011; Norrgard, 2009).

\section{History}

During the $19^{\text {th }}$ and $20^{\text {th }}$ centuries berrying was an important form of labor that brought economic sustenance to the Ojibwe tribe of Wisconsin and Michigan. ${ }^{2}$ In their 1837 and 1842 treaties with the United States, the Ojibwe leaders reserved the right to fish, hunt and gather on ceded land (Norrgard, 2009). While non-Natives were interested in lumber, the Ojibwe people sought to protect major food and clothing resources. During the 1837 negotiations an Ojibwe leader stated:

My father. Your children are willing to let you have their lands, but they wish to reserve the privilege of making sugar from the trees and getting their living from the Lakes and Rivers, as they have done heretofore, and of remaining in this Country. It is hard to give up the lands. They will remain, and cannot be destroyed-but you may cut down the Trees, and others will grow up. You know we cannot live, deprived of Lakes and Rivers; There is some give on the lands yet; \& for that reason also, we wish to remain upon them, to get a living. Sometimes we scrape the trees and eat of the bark. The Great Spirit above, made the Earth, and causes it to produce, which enables us to live (Norrgard, 2009).

Historians note that blueberries were not explicitly mentioned in treaty negotiations but agree that they were included under plant resources due to the role of berrying in the

\footnotetext{
${ }^{1}$ According to the USDA, over 50 varieties of blueberries grown in North America (USDA, 2012). Highbush and lowbush berries are among the most commercially popular in the US.

${ }^{2}$ Many northern territory Native Americans have consumed blueberries, however, the Ojibwe tribe provides some of the best records of their relationship with the berry.
} 
developing European American markets. (Sliver \& Allen, 2012; Norrgard, 2009)

By the time European settlers forced the removal of the Oijibwe community from their native lands to reservations in Wisconsin and Minnesota in the 1850s, berrying had become an important resource in Ojibwe economic survival. The migration of tribal families was dictated by crop production. One Ojibwe man recounts: "In the summer of 1872, we moved from Ontanogan with the whole family, paddling in birch bark canoes to Eagle River, Michigan, where we joined other Indians living at that place. Our occupation there was picking blueberries and huckleberries and selling them to procure the necessities of life" (Norrgard, 2009). Further, women who often had no male relatives turned to berrying as their major source of income because it was considered child-friendly labor (Norrgard, 2009). In 1940, one Ojibwe grandson remembers:

...the mother was not deterred from participating in the harvesting of natural, or wild, crops. These crops were the edible roots, nuts, berries, maple sugar, and wild rice... After cautioning the children to remain in the canoe, the mother picked berries within sight and sound of the children. The children played and slept in the raft the whole day occasionally partaking of the food and drink left for them by their mother... (Norrgard, 2009)

Ojibwe tribal tradition believes that all living things are gifts from the Great Spirit. Blueberries were eaten in raw form as well as in jellies, dried, and as juices (Sliver \& Allen, 2012; Moerman, 1998). Tribes called the berry the "star berry" due to the five-point star that forms at its calyx (the blossom end of the berry) (Sliver \& Allen, 2012; NAED, 2012). Blueberry tea was used medicinally to help cure chronic coughs and other common cold symptoms. Blueberry leaves were used to purify the blood during lesion care (Sliver \& Allen, 2012; NAED, 2012; Howell, 2009). Other Native American tribes also used the blueberry for medicinal purposes such as the Woods Cree tribe that used blueberry stems to speed up recovery following childbirth and to prevent miscarriages (Sliver \& Allen, 2012; NAED, 2012).

Ojibwe berrying also influenced non-Native American societies. Berrying provided an entry into the European American economy for Native Americans and a nutritious berry fruit for early American settlers. Settlers bought berries picked off reservation land from Natives to be eaten raw and in baked goods. "A few blueberries have been brought into town this week, but was all purchased promptly by our citizens for home consumption, at a shilling [about $\$ 0.8$ USD] a quart" reports the July 1883 edition of the North Wisconsin News (Norrgard, 2009). Soon American settlers began to hire Native for berrying on ceded land newly owned by the settlers (Norrgard, 2009). The settlers observed that the Natives would purposely set fire to portions of the blueberry fields every other year so production would continue annually (Silver \& Allen, 2012). With advances in cultivation knowledge in the 1900s, Americans began to operate their own blueberry farms (Sliver \& Allen, 2012; Kaplan, 2011).

Blueberry regions have emerged across the United States in, for example, New Jersey, Texas, and Michigan. Towns such as Hammonton, New Jersey have held "Red White and Blueberry Festivals" annually since the late 1980s (Donio, 2002). In 1984, President Ronald Regan crowned Hammonton the "blueberry capital of the world". Due to the vital role of the crop in the economy of this town, nearly every resident of Hammonton has a blueberry story. The festival is a symbol of the relationship between Hammonton's blueberry farmers and the highbush blueberry crop that has made the town famous and brought about economic stability (DeAngelis, 2011; Donio, 2002). Today, the festival receives nearly 10,000 blueberry guests (DeAngelis, 2011).

In the 1950s and 1960s, Texans began to research blueberry cultivation in their state (Reese, 1985). Blueberries are native to Eastern Texas. Researchers from Texas A\&M University utilized these varieties to learn about Texas blueberries. They found that there was a demand for increased acreage of blueberry production in Texas due to consumption. They also saw that blueberry varieties grown in the state also have a profitable niche because the Texas berry-growing season began a couple weeks before the northern berry-growing season (Lee, 1986). Much excitement surrounded blueberry farming. In the mid 1980s, Dallas newspapers reported that farmers had given up their soybean crop in exchange for blueberries because blueberries (Lee, 1986). A Texas Department of Agriculture administrator was quoted as saying, "It's the most exciting new crop to be developed in many, many years," (Lee, 1986).

Today, Michigan is the leading producer of highbush blueberries. The state gained this status in the mid-1980s, surpassing New Jersey. The sandy Kalkaska soil makes this region ideal for blueberries to thrive. The small city of South Haven, Michigan is home to the National Blueberry Festival, which has taken place annually since 1963 (Puhala, 1987). This festival is one of four blueberry festivals that take place in Michigan (Wood, 2008). The festival receives around 50,000 - 70,000 guests from all over the United States (Wood, 2008). Festivities include cook-offs, pie eating contests, $5 \mathrm{k}$ and $10 \mathrm{k}$ runs, and youth pageants, all in celebration of the blueberry.

Nationally, blueberries have become a symbol of American culture. In addition to having been highlighted in songs such as "Blueberry Hill", produced in 1940, the blueberry has been an integral part of American fruit medley imagery. Blueberries are widely featured as the main ingredient to pies, cakes, muffins, fruit salads and other delectable sweets. For Americans, red, white, and blueberry cakes have become a Fourth of July tradition. While the white portion of the cakes may have been comprised of sour cream, whipped cream or cream cheese and the red portion may have been raspberries, strawberries or watermelon, the blue portion has remained blueberries. One Michigan State University Department of Horticulture bulletin begins, "The blueberry is even more American than turkey for thanksgiving, for it was in this country in great abundance and was highly prized by the Indians before the white settlers arrived" (Johnston, 1959).

\section{Methods}

I searched the PubMed database for reviews on the phytochemical components of blueberries. Search terms included: blueberry or vaccinium, berry fruit or berries, phytochemicals/phytonutrients/bioactive compounds and cancer. Reviews were limited to those published in the last five years. Articles published in peer-reviewed journals across the globe were included. Articles about berry and berry-type fruits that did not consider blueberries were excluded. This search methodology was used in order to explore the biochemistry of blueberries and the bioactive compounds within blueberries that may be 
useful in the prevention and treatment of various cancers.

\section{Results}

Review articles present clear evidence of the influence of blueberries phytonutrients on brain functioning such as memory and learning (Rendeiro et al., 2012); energy metabolism, adiposity and obesity (Meydani \& Hasan, 2010); as well as cancer prevention and treatment (Seeram, 2008a). In addition, blueberry seed flours have disease-preventing capabilities (Parry et al., 2006). Table 1 shows the USDA (2012) nutritional facts per $100 \mathrm{~g}$ of blueberries and their respective percentage of daily-recommended amounts.

The anti-disease function of blueberries is mainly attributed to the antioxidant properties of their bioactive compounds. Though notes are made about variation given the type of blue

Table 1.

Blueberry (Vaccinium spp) nutrition facts ${ }^{\mathrm{a}}$, per $100 \mathrm{~g}$.

\begin{tabular}{|c|c|c|}
\hline Principle & Nutrient Value & $\begin{array}{c}\% \text { of Daily } \\
\text { Recommendation }\end{array}$ \\
\hline Energy & $57 \mathrm{Kcal}$ & $3 \%$ \\
\hline Carbohydrates & $14.49 \mathrm{~g}$ & $11 \%$ \\
\hline Protein & $0.74 \mathrm{~g}$ & $1 \%$ \\
\hline Total Fat & $0.33 \mathrm{~g}$ & $1 \%$ \\
\hline Cholesterol & $0 \mathrm{mg}$ & $0 \%$ \\
\hline Dietary Fiber & $2.4 \mathrm{~g}$ & $6 \%$ \\
\hline \multicolumn{3}{|l|}{ Vitamins } \\
\hline Folates & $6 \mu \mathrm{g}$ & $1.5 \%$ \\
\hline Niacin & $0.418 \mathrm{mg}$ & $2.5 \%$ \\
\hline Pantothenic acid & $0.124 \mathrm{mg}$ & $2.5 \%$ \\
\hline Pyridoxine & $0.052 \mathrm{mg}$ & $4 \%$ \\
\hline Riboflavin & $0.041 \mathrm{mg}$ & $3 \%$ \\
\hline Vitamin A & $54 \mathrm{IU}$ & $2 \%$ \\
\hline Vitamin C & $9.7 \mathrm{mg}$ & $1.5 \%$ \\
\hline Vitamin E & $0.57 \mathrm{mg}$ & $4 \%$ \\
\hline Vitamin K & $19.3 \mu \mathrm{g}$ & $13 \%$ \\
\hline \multicolumn{3}{|l|}{ Electrolytes } \\
\hline Sodium & $1 \mathrm{mg}$ & $0 \%$ \\
\hline Potassium & $77 \mathrm{mg}$ & $2 \%$ \\
\hline \multicolumn{3}{|l|}{ Minerals } \\
\hline Calcium & $6 \mathrm{mg}$ & $0.5 \%$ \\
\hline Iron & $0.28 \mathrm{mg}$ & $3.5 \%$ \\
\hline Magnesium & $6 \mathrm{mg}$ & $1.5 \%$ \\
\hline Manganese & $0.336 \mathrm{mg}$ & $14 \%$ \\
\hline Zinc & $0.16 \mathrm{mg}$ & $1.5 \%$ \\
\hline
\end{tabular}

${ }^{\mathrm{a} U S D A 2012 .}$ berry studied, the literature finds that blueberries are rich in anthocyanins, flavanoids, phenolic acids, and stilbenes (Brown et al., 2012; Rendeiro et al., 2012; Varoni et al., 2012; Mates et al., 2011; Meydani \& Hasan, 2010; Seeram, 2008a; Szajdek \& Borowska, 2008). Flavanoids, such as proanthocyanidins (condensed tannins) and anthocyanins are polyphenolic compounds that are typically found in the skin of blueberries. Resveratrol is a stilbene also found in the skin of blueberries; it acts as a defense mechanism for berry fruits (Goswami, 2009; Udenigwe, 2008).

Articles that focus on the anti-cancer properties of blueberries and berry fruits, mostly consider anthocyanins (Brown et al., 2012; de Kok et al., 2012; Varoni et al., 2012; Mates et al., 2011; Stan et al., 2008). This flavonoid has been shown to act as an antioxidant. Antioxidants are "scavengers of various oxidizing species, such as hydroxyl radical ( $\left.{ }^{\circ} \mathrm{OH}\right)$, peroxy radicals ('OOR) or superoxide anion radical $\left(\mathrm{O}_{2}{ }^{\circ}\right)$, due to the presence of a catechol group in conjunction with several hydroxyl groups" (Mates et al., 2011). Moreover, flavonoids effect cell proliferation and help regulate cancer signal transduction pathways (Collins et al., 2012; Mates et al., 2011). For example black raspberry, red raspberry, blueberry, and cranberry seed flours inhibit the proliferation of human HT29 colon cancer cell line (Parry et al., 2006). In a very informative review published in the Journal of Agriculture and Food Chemistry, Dr. Navindra P. Seeram (2008a) summarizes:

Berry fruits have also been shown to inhibit the activities of enzymes, which play a significant role in cancer metastasis, such as matrix metalloproteinases (MMPs). A recent study (2006) investigated the ability of flavonoidenriched fractions from low bush blueberry to downregulate MMP activity in DU145 human prostate cancer cells. Differential down-regulation of MMPs was observed in cells exposed to both anthocyanin-and proanthocyanidin-enriched blueberry fractions. The possible involvement of protein kinase-C and mitogen-activated protein kinase pathways in the flavonoid-mediated decreases in MMP activity was observed. The authors concluded that the down-regulation of MMP activities by the blueberry flavonoids might occur through multiple mechanisms.

Recent literature also pays attention to the anti-cancer properties of resveratrol. Red wine is popularly known to contain resveratrol from the red grapes. Resveratrol is also found in blueberries in moderate quantities (Brown et al., 2012; Goswami, 2009). Resveratrol influences cancer at the initiation, promotion and progression stages during the development of cancer (Udenigwe, 2008). It can induce apoptosis in various cancer cells without killing normal cells (Udenigwe, 2008). Resveratrol also aids in the reduction of inflammatory diseases (Brown et al., 2012; Udenigwe, 2008).

Finally, articles agree that the bioactive compounds within blueberries aid in the prevention of a number of cancers including breast, colon, esophageal, liver, ovarian, and prostate (Brown et al., 2012; de Kok, 2012; Varoni et al., 2012; Mates et al., 2011; Seeram, 2008a; Stan et al., 2008; Parry et al., 2006).

\section{Discussion \& Conclusion}

Increased consumption of berry fruits can help in the prevention of various cancers in a number of ways. Physiologically, 
prior research has found that the antioxidant properties of berries fight off free radicals in the body produced by oxidative stress and the anti-cancer properties of berries protect against DNA damage and induce apoptosis within cancer cells (Goswami, 2009). Culturally, prior research has found that certain populations have unique connections with the health promoting fruits (Norgard, 2009). It is clear that the evolution of these fruits is largely influenced by their cultivation by human populations. Wild blueberry bushes grow taller with large, plump fruits. The Ojibwe people are an example of a population whose geographic patterning and nutritional survival was influenced by the growth patterns of blueberries.

\section{Cultural Competence}

A nation-wide fruit and vegetable consumption program, entitled the "5 A Day Program" was instituted by the National Cancer Institute (NCI) and the Produce for Better Health Foundation in 1991 (Pivoka, 2011). The purpose of this campaign was to improve awareness and consumption of fruits and vegetables within American society. At the program's advent, only $8 \%$ of individuals reported being aware that they should consume at least 5 servings of fruits and vegetables per day (Stables, 2002). By 2005, when the NCI gave lead authority of the program over to the CDC, this awareness had increased to $40 \%$ (National Cancer Institute, 2004). Unfortunately, researchers have found that for the majority of Americans this heightened awareness has not translated to heightened consumption of fruits and vegetables (Pivoka et al., 2011). Cultural competence on the part of health professionals may help to change this lack of consumption through broader lines of communication and familiar starting points for patients.

The movement towards personalized medical care has recognized the importance of culturally competent providers (Beach et al., 2005). There is a difference, however, between patient centered care and culturally competent personalized care. Cultural competence can be defined as:

.... a set of congruent behaviors, attitudes, and policies that come together in a system, agency, or among professionals that enables effective work in cross-cultural situations, where "culture" refers to integrated patterns of human behavior that include the language, thoughts, communications, actions, customs, beliefs, values, and institutions of racial, ethnic, religious, or social groups, and "competence" implies having the capacity to function effectively as an individual or an organization within the context of the cultural beliefs, behaviors, and needs presented by patients and their communities (American Association of Medical Colleges, 2010).

Within this framework, culturally competent personalized care focuses on the unique sociocultural background of a person as opposed to solely a patient with a specific cancer or illness (Beach et al., 2005). Cultural competence does improve patient satisfaction and clinician attitudes and skills (Beach et al., 2005). Through increased knowledge, healthcare professionals have a broader context in which they can encourage the health and strength of their patients.

Cultural competence must be used in all aspects of public health, including the marketing and promotion of health promoting behaviors such as blueberry consumption. Two major arguments can be made connecting berries, human disease and cultural competence within healthcare. First, knowledge of both the nutritional and cultural benefits of berries can aid in giving healthcare providers the social capital needed to communicate across ethnic boundaries. Clinicians and patients often build trust on the basis of shared knowledge. For example, knowing that Native Americans knew blueberries as the "star berries" may be a common-ground conversation starter for clinicians working with Ojibwe people or those with similar Native American ancestry. To Americans from past and present immigrant ancestry, blueberries are symbolic of the reds, whites and blues of the United States, especially on the fourth of July. Food often acts as a pathway to deeper relationship. For instance, when conversations surround a relative's amazing blueberry muffins or the best recipe for blueberry pie. Why not utilize this knowledge of solidarity around food to encourage healthier and consistent consumption patterns?

Second, exploring berries in the context in which they were cultivated can help scientists further understand the dietary patterns and disease susceptibility of specific populations. From a plant-human coevolutionary standpoint, understanding the dietary patterns of early hunter-gathering societies and their evolution to agriculture has helped us draw conclusions about the increased prevalence of various disease types. The same can be true in the movement towards personalized drug therapies. Nutrients or phytonutrients found in the diets of ethnic ancestors can help scientists understand how certain populations have come to be more susceptible to certain cancers and not others. Knowing the context in which these berries were consumed helps scientists understand the environmental components and social stressors that may have contributed to various gene expression or epigenetic mutations. Research is needed which examines this intersection of plant-human culture, chemistry, and human disease processes.

\section{Acknowledgements}

Special thanks to Dr. Fatimah Jackson as well as my colleagues in Anthropology 699: Human-Plant Coevolution from where this paper was cultivated.

\section{REFERENCES}

American Association of Medical Colleges (2010). Cultural competence education for medical students. https://www.aamc.org/

Beach, M. C., Price, E. G., Gary, T. L., Robinson, K. A., Gozu, A., Palacio, A., Smarth, C., Jenckes, M. W., Feuerstein, K. A., Bass, E. B., Powe, N. R., \& Cooper, L. A. (2005). Cultural competency: A systematic review of health care provider educational interventions. Medical Care, 43, 356. doi:10.1097/01.mlr.0000156861.58905.96

Beach, M. C., Gary, T. L., Price, E. G., Robinson, K., Gozu, A., Palacio, A., Smarth, C., Jenckes, M. W., Feuerstein, K. A., Bass, E. B., Powe, N. R., \& Cooper, L. A. (2006). Improving health care quality for racial/ethnic minorities: A systematic review of the best evidence regarding provider and organization interventions. BMC Public Health, 6, 104. doi:10.1186/1471-2458-6-104

Bianco, M. (1988). True blueberries are an all-American fruit. San Francisco, CA: The San Francisco Chronicle.

Brown, E. M., Gill, C. I. R., McDougall, G. J., \& Stewart, D. (2012). Mechanisms underlying the anti-proliferative effects of berry components in in vitro models of colon cancer. Current Pharmaceutical Biotechnology, 13, 200-209. doi:10.2174/138920112798868773

Centers for Disease Control-Cancer Prevention and Control (CDC) (2012). http://www.cdc.gov/cancer/

Collins, A. R., Azqueta, A., \& Langie, S. A. S. (2012). Effects of micronutrients of DNA repair. European Journal of Nutrition, 51, 261- 


\section{N. SAMUEL-PETERSON}

279. doi:10.1007/s00394-012-0318-4

DeAngelis, M. (2011). Sand in my shoes/singing (the praises of) the blues/hammonton prepares to once again celebrate the blueberry and its farmers (p. B1). Atlantic, NJ: The Press of Atlantic City.

Goswami, S. K., \& Das, D. K. (2009). Resveratrol and chemoprevention. Cancer Letters, 284, 1-6. doi:10.1016/j.canlet.2009.01.041

Howell, A. B. (2009). Update on the health benefits of cranberry and blueberry. Acta Horticulturae, 810, 779-784.

Johston, S. (1959). Essentials of blueberry culture. East Lansing, MI: Department of Horticulture, Michigan State University Agricultural Experiment Station.

Kaplan, J. K. (2011). Blueberry growing comes to the national agricultural library. Agricultural Research, 59, 14-16.

de Kok, T. M. C. M., van Breda, S. G. J., \& Briede, J. J. (2012). Genomics-based identification of molecular mechanisms behind the cancer preventative action phytochemicals: Potential and challenges. Current Pharmaceutical Biotechnology, 13, 255-264. doi:10.2174/138920112798868601

Mates, J. M., Segura, J. A., Alonso, F. J., \& Marquez, J. (2011). Anticancer antioxidant regulatory functions of phytochemicals. Current Medicinal Chemistry, 18, 2315-2338. doi:10.2174/092986711795656036

Mahadevan, B., Mata, J. E., Albershardt, D. J., Stevens, J. F., Pereira, C. B., Rodriguez-Proteau, R., Baird, W. M. (2005). The effects of red raspberry extract on PAH transport across Calu-3 cell monolayer, an in-vitro cell model. International Journal of Cancer Prevention, 2, 129-141.

Meydani, M., \& Hasan, S. T. (2010). Dietary polyphenols and obesity. Nutrients, 2, 737-751. doi:10.3390/nu2070737

Moerman, D. E. (1998). Native american ethnobotany. Portland, Oregon: Timber Press.

Native American Ethnobotany Database (NAED) (2012). http:/herb.umd.umich.edu

Norrgard, C. (2009). From berries to orchards: Tracing the history of berrying and economic transformation among Lake Superior Ojibwe. The American Indian Quarterly, 33, 33-61.

doi:10.1353/aiq.0.0035

Pallas, L. A., Pegg, R. B., \& Kerr, W. L. (2012). Quality factor, antioxidant activity, and sensory properties of jet-tube dried rabbiteye blueberries. Journal of the Science of Food and Agriculture, Published Online Wiley Library. doi:10.1002/jsfa.5985

Parry, J., Su, L., Moore, J., Cheng, Z., Luther, M., Rao, J. N., Wang, J., \& Yu, L. L. (2006). Chemical compositions, antioxidant capacities, and antiproliferative activities of selected fruit seed flours. Journal of Agricultural and Food Chemistry, 54, 3773-3778. doi: $10.1021 / \mathrm{jf} 060325 \mathrm{k}$

Pivonka, E., Seymour, J., McKenna, J., Baxter, S. D., \& Williams, S. (2011). Development of the behaviorally focused fruits \& veggiesMore matters public health initiative. Journal of the American Dietetic Association, 111, 1570-1577. doi:10.1016/j.jada.2011.07.001

Puhala, B. (1987). It's blueberry time in Grand Haven. Chicago, IL: Chicago-Sun Times.

Reagan, R. (1984). Remarks at a Reagan-Bush rally in Hammonton, New Jersey. Public Papers of Ronald Reagan: September 1984. http://www.reagan.utexas.edu/archives/speeches/1984/91984c.htm.

Reese, S. (1985). It takes dedication to grow Texas blueberries. Dallas, Tx: The Dallas Morning News.

Rendeiro, C., Guerreiro, J. D. T., Wiliams, C. M., \& Spenser, J. P. E., (2012) 70th Anniversary Conference on "From plough through practice to policy": Postgraduate symposium flavonoids as modulators of memory and learning: Molecular interactions resulting in behavioural effects. Proceedings of the Nutrition Society, 71, 246-262. doi:10.1017/S0029665112000146

Seeram, N. P. (2008a). Berry fruits for cancer prevention: Current status and future prospects. Journal of Agricultural and Food Chemistry, 56, 630-635. doi:10.1021/jf072504n

Seeram, N. P. (2008b). Symposium: Berry fruits: Compositional elements, biochemical activities, and the impact of their intake on human health performance, and disease. Journal of Agricultural and Food Chemistry, 56, 627-629. doi:10.1021/jf071988k

Seeram, N. P. (2011). Emerging research supporting the positive effects of berries on human health and disease prevention. Journal of Agricultural and Food Chemistry, 60, 5685-5686. doi: $10.1021 / \mathrm{j} f 203455 \mathrm{z}$

Siegel, R., Naishadham, D., \& Ahmedin, J. (2012). Cancer statistics, 2012. CA Cancer Journal for Clinicians, 62, 10-29. doi: $10.3322 /$ caac. 20138

Silver B. \& Allen, M. (2012). Commodity of the quarter: Blueberries. Journal of Agricultural \& Food Information, 13, 7-13. doi: $10.1080 / 10496505.2012 .639664$

Smith, H. (1932). Ethnobotany of the Ojibwe Indians. Bulletin of the Public Museum of Milwaukee, 4, 327-525.

Stables, G. J., Subar, A. F., Patterson, B. H., Dodd, K., Heimendinger, J., Van Duyn, M. A., \& Nebeling, L. (2002). Changes in vegetable and fruit consumption and awareness among US adults: Results of the 1991 and 19975 a day for better health program surveys. Journal of the American Dietetic Association, 102, 809-817. doi:10.1016/S0002-8223(02)90181-1

Stan, S. D., Kar, S., Stoner, G. D., \& Singh, S. V. (2008). Bioactive food components and cancer risk reduction. Journal of Cellular Biochemistry, 104, 339-356. doi:10.1002/jcb.21623

Stoner, G. D., \& Seeram, N. P. (Eds). (2011). Berries and cancer prevention. New York: Springer.

Szajdek, A., \& Borowska, E. J. (2008). Bioactive compounds and health-promoting properties of berry fruits: A review. Plant Foods and Human Nutrition, 63, 147-156. doi:10.1007/s11130-008-0097-5

Thompson, J. (2005). The geographic mosaic of coevolution. Chicago, IL: University of Chicago Press.

Tonge, P. (1980). For overseas visitors, blueberries were a hit. Boston, MA: The Christian Science Monitor.

Udenigwe, C. C., Ramprasath, V. R., Aluko, R. E., \& Jones, P. J. H. (2008). Potential of resveratrol in anticancer and anti-inflammatory therapy. Nutrition Reviews, 66, 445-454. doi:10.1111/i.1753-4887.2008.00076.x

Umezawa, T. (2003). Diversity in lignin biosynthesis. Phytochemistry Reviews, 2, 371-390. doi:10.1146/annurev.arplant.54.031902.134938

United States Department of Agriculture (USDA) (2012). http://www.ars.usda.gov

Varoni, E. M., Lodi, G., Sardella, A., Carrassi, A., \& Iriti, M. (2012). Plant polyphenols and oral health: Old phytochemicals for new fields. Current Medicinal Chemistry, 19, 1706-1720. doi: 10.2174/092986712799945012

Wood, M. (2011). Blueberries and your health: Scientists study nutrition secrets of popular fruit. Agricultural Research, 59, 9-13.

Wood, W. R. (2008). South Haven's 45th national blueberry festival celebrates more than just berries. Kalamazoo, MI: Kalamazoo Gazette.

Wu, X., Beecher, G. R., Holden, J. M., Haytowitz, D. B., Gebhardt, S. E., \& Prior, R. L. (2004). Lipophilic and hydrophilic antioxidant capacities of common foods in the United States. Journal of Agricultural and Food Chemistry, 52, 4026-4037. doi:10.1021/jf049696w 